Timothy Hassall

\title{
Individual Variation in L2 Study-Abroad Outcomes: A Case Study from Indonesian Pragmatics
}

\begin{abstract}
This is a study of two Australian learners of Indonesian during a short stay abroad. It examines their contrasting success in acquiring L2 address terms, in tandem with their contrasting experiences of the L2 culture setting. It thereby helps explain the persistent finding of great individual variation in L2 gains and in particular pragmatic gains - during study abroad. The study shows that the contrasting success of these two learners is linked to their L2 identity development. At the same time, it dispels a simplistic view of the relationship between identity development and pragmatic development, by showing that their language outcomes emerge through a highly contingent process. The study also helps us understand how certain specific factors can influence learning of L2 pragmatics during study abroad, such as low initial proficiency, prior foreign language learning experience, timing of formal instruction, and the presence of peer L2 learners during naturalistic interactions.
\end{abstract}

Keywords: L2 pragmatics, individual variation, study abroad, address terms, Indonesian

DOI 10.1515/multi-2013-0050

\section{Introduction}

This article takes as its point of departure a previous finding (Hassall 2013) that a cohort of study abroad learners during a short stay in Indonesia showed little development overall with regard to learning the correct pronouns in Indonesian forms of address. Not discussed in that study, however, is that this overall trend of modest development concealed great individual variation. In fact, a small number of learners bucked that trend by making striking gains. This article aims to help us understand the greatly varying success of second language (L2)

Timothy Hassall, Australian National University, Canberra, ACT 0200, Australia, E-mail: timothy.hassall@anu.edu.au 
learners during study abroad, by examining in a contrastive light the learning and the experiences of two individuals from that cohort: one who learned a great deal and one who did not. This article will briefly examine the literature on three issues: individual difference in L2 gains during study abroad, the influence of initial proficiency on those gains, and the role of L2 identity in L2 development, before moving on to the contrastive study.

\section{Individual differences in study-abroad gains}

Study abroad learners tend to make modest but definite gains in L2 pragmatics (for a recent overview of empirical findings, see Hassall 2012a). However, a persistent finding is that individual participants vary greatly in how much they learn (e.g. DuFon 2000; Kinginger 2008). This also is true for learning in domains of L2 competence other than pragmatics, such as oral proficiency (see e.g. Ginsberg \& Miller 2000; Kinginger 2009). This great individual variation resists attempts to explain it in terms of quantifiable factors, such as amount of L2 exposure or L2 interaction during the sojourn (Ginsberg \& Miller 2000). Rather, it seems to emerge from the precise qualities of an individual's experiences during their stay abroad (e.g. Kinginger 2009). To understand how that happens, we must closely examine the experiences of individual learners during their stay, along with their L2 development (see Block 2003; Kinginger 2009).

There is a gap in the research regarding this kind of examination, with the exception of a small number of studies (DuFon 2000; Ginsberg \& Miller 2000; Kinginger 2008; Shively 2008, 2013). This present study will contribute insights regarding how participants' stances toward learning and the host country can influence L2 pragmatic development during study abroad.

\section{L2 proficiency and study abroad}

As the participants in this study are of low initial proficiency, we should ask whether that factor disadvantages L2 learners of pragmatics during study abroad. It has been claimed that learners with low proficiency are below a threshold level of L2 competence necessary to be able to benefit from the informal L2 environment offered by study abroad. Their low lexico-grammatical knowledge base places a high cognitive burden on their working memory, which prevents them from processing or producing long strings of linguistic material - such as complex pragmalinguistic realizations (see Lafford \& Collentine 2006; Bardovi-Harlig 2013). 
On the other hand, we can find empirical instances of successful pragmatic learning by low-proficiency learners during study abroad. Low level US learners of Spanish show impressive pragmatic gains in acquiring formally simple opening and closing routines (Marriott 1995). One beginner US learner of Indonesian made the most striking progress in learning address terms of any of the six learners in the mixed-ability cohort, during her four-month stay abroad (DuFon 2000). On the whole, it appears that low initial proficiency is a potential obstacle for learning pragmatics during study abroad, but that it need not stop learners from making impressive gains with regard to some formally simple pragmatic features.

\section{L2 identities}

One perspective on L2 development is to view language as a site of identity construction (Pavlenko 2002; Norton \& McKinney 2011). The range of identities available to a learner within the L2 setting influences the outcomes of their learning in two ways. It does so by affecting the learner's access to L2 linguistic resources and by affecting the learner's agencies and investments in learning the language (Pavlenko 2002). Learning L2 pragmatics, in particular, is likely to be bound up with L2 identity formation, due to the intrinsic location of L2 pragmatics "at the crossroads of the cognitive and the social" (Block 2003: 138). This certainly appears to be true for acquiring address terms, specifically. In a study by Kinginger (2008), one learner of French eschews use of familiar tu to young fellow university students in order to maintain his sense of his own identity within the L2 culture setting. In two studies by Hassall (2012b, 2013), Australian learners who feel strongly positioned as foreigners within their L2 culture setting display a reluctance to adopt certain address term practices which they perceive as normative. DuFon's (2000) findings are also telling. Her six mixed nationality learners made greatly varying gains in their knowledge and use of Indonesian address terms during their four-month sojourn, and that variation seems linked to their identity development. The beginner learner who made the most striking progress displayed at the same time a strong respect for Indonesian cultural values which determine address term choice, particularly values of hierarchy. By contrast, another beginner who made very little progress - relying on a single term (anda) indiscriminately to all addressees - revealed a relatively low concern for those values (DuFon 2000: 462-463). In summary, low-proficiency participants during study abroad often do succeed in learning certain pragmatic features, including address terms, and individual participants vary greatly in how much pragmatics they learn which may be linked to their identity development. 


\section{Address terms in Indonesian}

Several Indonesian address terms are particularly important to this study, these include kin terms (Section 5.1), vocative slot versus pronoun slot (Section 5.2), and the pronouns anda and kamu (Section 5.3).

\subsection{Kin terms}

The "parent" kin terms ( $B a$ )pak and (I)bu literally mean "father" and "mother" respectively. They are typically used to an adult male or female of fairly mature years or of higher position than the speaker, to show respect (see Jenson 1988). The "sibling” kin terms Mas and Mbak mean "older brother" and "older sister" respectively. They may convey a message of solidarity or equality with the addressee or may convey a neutral message instead, "with no implications of equality but also with no show of respect or disrespect” (Jenson 1988: 131).

\subsection{Vocative slot versus pronoun slot}

All the kin terms mentioned above occur in both the vocative slot and the pronoun slot. That distinction is illustrated in the examples below:

(1) Selamat pagi, Ibu. safe morning mother "Good morning, mother".

(2) Kapan Ibu ke sana? when mother to there "When did you go there?"

In Extract (1), the term Ibu is used in the vocative slot. It occurs outside the structure of the main clause, in an optional slot. In Extract (2), Ibu is used in the pronoun slot instead. It occurs in the main clause structure, in subject position, with a parallel function to the word "you" in English.

\subsection{Pronouns: anda and kamu}

The pronoun anda was coined by central language planners in the 1950s, who intended it to become a neutral, all-purpose pronoun, similar in the role served 
by "you" in English (DuFon 2000). However, anda failed to assume that function. The pronoun anda is very formal in register and conveys a message of very high social distance. It is very rarely used in conversation between Indonesians. However, in line with that official and purely theoretical notion that anda is a neutral pronoun, anda tends to be emphasized in formal classroom teaching of the language to foreign students - a teaching practice which contradicts the reality of actual language use.

Kamu is a familiar pronoun. It is used mainly to address people who one knows very well and who are of equal or lower status, or to address children (DuFon 2000). It is also sometimes used among young people who don't know each other well but who share group membership; for example among university students on campus, where it indexes youth solidarity.

\section{The study}

This study is part of a larger project on address term development by 12 learners from Australia during a sheltered study abroad program in Indonesia. The program was an intensive language course (with a small additional component of culture study) of four- or seven-week duration. It was run for foreign students at a language center attached to a private Christian university, in a large town in Central Java with a large Christian population, while the students lived in a homestay setting. The first stage of the study (reported in Hassall 2013) examined overall trends of address term development for the cohort. This second stage examines individual variation in development, through case studies of two members of the cohort who stayed for four weeks. The research questions are as follows: (1) What was the development of each of the two individuals with regard to knowledge about L2 address terms? (2) How did their identity development influence their learning of address terms?

\section{Methodology}

\subsection{Methods of data collection}

The study uses a multi-method approach: a written pre-test/post-test, three interviews with each participant, and regular diary-keeping tasks. In the written test instrument, the two participants were presented with seven scenarios in 
which they imagined themselves talking with a different person each time and were asked to choose an address term to address that person. After writing their response, they were asked to comment orally on that choice. In three of the test scenarios the addressee is higher in status than the speaker, or is a good deal older than the speaker, or both. These three addressees are: a homestay mother, the director of the language school, and a 50-year-old rickshaw driver. To these three addressees, only the respectful parent kin terms Bapak/Ibu are acceptable. In three other test scenarios, the addressee is young, and of equal status or lower status than the speaker, and not an intimate of the speaker. These three addressees are: a fellow customer at a roadside eating stall, a student who works in the computer lab at the language school, and a servant in the speaker's homestay. To these three addressees, the sibling kin terms Mas and Mbak are the most appropriate choices. In one test scenario, the addressee is a close familiar of the speaker and of equal status to the speaker; namely, a local student whom the speaker has come to know well socially. To this addressee the term kamu is highly appropriate.

\subsection{Procedure}

Before departure, the two participants each participated in an individual session with the researcher, held at their home university. In this session they were interviewed about their previous study of Indonesian, exposure to other languages and cultures, and expectations regarding the study abroad experience. One of the two participants also completed the pre-test during her pre-departure session. The other participant, who was a zero beginner, was instead shown the test instrument and invited to comment on the task. While in-country, the two participants were assigned two sets of diary-keeping tasks on their learning of pragmatics. Their first set was to contain at least two entries on address terms; and their second set was to contain at least three. ${ }^{1}$ The two participants were each interviewed individually by the researcher after submitting each set of diary entries. The first interview was held about half-way through their fourweek course, and the second interview was held shortly after the end of the course, back at the home university. In each of these meetings the participants were asked to clarify individual diary entries, asked about their daily interactions, and asked about their impressions and evaluations of their experience of

1 This study of address terms is part of a larger project on pragmatic development which examines three features: address terms, leave-taking, and complaints. Participants were instructed to make their remaining diary entries on leave-taking and complaining. 
living there. ${ }^{2}$ In their last meeting, the two participants also completed the posttest activity. All sessions were audio-recorded with a digital voice recorder, and the data were transcribed.

\section{Ross}

\subsection{Background}

"Ross" (names of all people mentioned in this paper are pseudonyms) is a lively, Australian, Caucasian male student in his mid-twenties, who speaks English as his first language, with an exceptionally warm and open manner. He had begun to study languages at university twice before - first Japanese, and then Chinese - but both times he had come to dislike the formal language program and had withdrawn before the end of the first year. He said he remembers wishing fervently when he began both those language programs that he could start them with an initial year of immersion in the target culture instead. He remarked: "I consider that the best and easiest [...] way to learn a language [...] - and you'll learn a lot more about the culture as well" [pre-departure interview]. This belief of Ross has much in common with the "folklinguistic theories of language learning" held by many study abroad participants (Miller \& Ginsberg 1995). Ross had traveled abroad a good deal, backpacking in Europe, with odd jobs along the way. He had also once spent six months living in a small town in Germany, on a study program. During that time, he said, he learned to converse in German "to an intermediate level" almost entirely through informal interaction. He remarked that "I love being thrown into situations where I'm forced to communicate in the language to get what I want" [pre-departure interview]. He added that he has "a bit of a passion for learning languages", and that he expects Indonesian to be "pretty easy" for him to learn [pre-departure interview]. Ross was a zero beginner in Indonesian. His main motive for switching to the Indonesian program was practical: Indonesian was the only Asian language program at his university that allowed accelerated progress through the language major by means of short summer courses for degree credit. However, he was also greatly looking forward to his summer course:

(3) I'm passionate about travel - it's something that burns inside me - I really really love meeting people from different cultures and experiencing that -

2 The set tasks of keeping a diary and discussing address terms with the interviewer might have raised the awareness of participants about address terms to some extent. 
and I guess because I've never come across Indonesian culture in my life I get kind of - like giddy and excited thinking about it - it's going to be awesome to experience that - a brand new culture [pre-departure interview].

Ross thus embarked on his sojourn equipped with certain skills, knowledge, and dispositions that are highly advantageous for language learning during study abroad and which can be regarded as a form of "mobility capital" (MurphyLejeune 2002). These include his extensive experience of foreign travel and zest for foreign travel; his considerable experience of learning languages, including through naturalistic interaction; and his confidence, even relish, in his ability to thrive in settings where he does not know the language.

\subsection{Ross's knowledge of address terms before departure}

Ross could not do the pre-test as he knew no Indonesian. However, he was shown the written test instrument, which requires students to choose a term of address to a range of addressees, and was invited to comment on that task. Ross said: "okay - thinking of my Japanese study - where the word 'you' can be quite offensive? - like - a direct - like the word anata - like you - you wouldn't use that in polite conversation - [...] a:nd - well - in Japanese there are different ways you can say you - it depends" [pre-test]. Ross displays an inclination here to interpret Indonesian address term practices by consulting his interlanguage (IL) knowledge of Japanese. That IL knowledge includes an element directly relevant to his learning of Indonesian during his stay: the perception that an L2 pronoun may equate to English "you" in some respects but at the same time be more restricted in its frequency and distribution than the pronoun "you" is in English.

\subsection{Ross and his L2 environment: first two weeks}

During his flight to Indonesia, Ross read an Indonesian phrasebook for travelers. As soon as he stepped off the plane, he "went into full absorption mode", trying to glean as many words and expressions from everyday encounters as he could [interview, Day 12/28]. While he was still in the airport, he heard people using several expressions he had read in his phrasebook, such as Terima kasih: receive-love, i.e. "Thank you", and used those expressions himself [interview, Day 12/28]. Ross's homestay environment proved a rich site for 
L2 exposure and practice. Ross lived with his two host parents (aged around 40), their two young children, and one fellow Australian guest, Leo, who was a low-intermediate student. Ross and Leo chatted together a lot with the two host parents each day, about a wide variety of topics [interview, Day 12/28].

If Ross, as a beginner speaker, had been the only foreign guest in the house, the conversations with the host parents would probably have been almost exclusively in English, because both host parents spoke English well, particularly the mother. However, the presence of Leo as a more proficient learner of Indonesian helped to tilt the choice of code toward Indonesian. Ross explained: “Because I'm in Level 1 and Leo's in Level 3 [the host parents] will generally translate everything - like - they might say something - in Indonesian? - and then they'll just say it in English [...] or else Leo will translate it for me" [interview, Day 12/28]. Ross was therefore exposed to a lot of Indonesian, of a simplified nature, which was also largely translated for his benefit. Ross also interacted a good deal with the two children in the house, who knew some English from school. He said "there's lots of chit-chat [with them] actually [...] and I try to use Indonesian words whenever I can" [interview, Day 12/28]. He and Leo played a lot of bilingual scrabble with the children ("we'll put down Indonesian words and they put down English words - it's really fun") [interview, Day 12/28]. They watched a lot of American cartoons with the children on $\mathrm{TV}$, often watching the same episode twice, first in English, and then a second time dubbed into Indonesian; both times accompanied by Indonesian subtitles. Ross talked in enthusiastic detail about the language benefits of this ("it's really helpful - watching both versions [...]" [interview, Day 12/28]). In reporting the above activities, Ross displays a strong identity as an informal language learner: he sees himself as learning the language largely through participation in everyday interactions.

Outside the house, as well, Ross had a great deal of informal exposure to and use of Indonesian. When he went out into town after classes, he was always in the company of someone; nearly always Leo, and during these outings they talked quite a lot with strangers: "Shopkeepers for example - try to strike up conversations with us-(laughs) - like - how old are you - where do you li:ve where are you fro:m - do you have a girlfriend - where is your family: - and stuff like this" [interview, Day 12/28]. Ross said he could handle many of these questions himself, since they mostly used the same basic type of vocabulary he is doing in class, and added "Leo's there too if I need him (laughs)" [interview, Day 12/28]. Thus, Leo as a more advanced fellow L2 learner played a supportive role in Ross's L2 speaking development in informal contexts (cf. Magnan \& Back 2007). 


\subsection{Ross and address terms: first two weeks}

Ross quickly learned a good deal about address terms. He reported on his fourth day "I have discovered the use of many terms" and listed the kin terms Bapak, $I b u$, and Mas, as well as the pronoun anda (and one rather obscure term, Bung) [diary entry, Day 4/28]. Most strikingly, Ross's learning included major knowledge about terms for the pronoun slot (discussed below).

\subsubsection{Vocative slot}

Ross learned of Bapak "father" and Ibu "mother" as vocative terms from a variety of sources. He noticed them in the pre-course orientation talk by the director, when she introduced the teachers to the gathering as, for example, "Ibu Linda" or "Bapak Marcus". He also learned them in classes, where his class practiced Bapak/Ibu in the vocative slot from the very first lesson, in phrases such as "Selamat Pagi, Ibu” [safe-morning-mother', i.e. "Good morning, mother”], and he also noticed his housemate Leo using Bapak/Ibu in the vocative slot to their host parents at home [interview: Day 12/28]. Ross also started very early to use Bapak and $I b u$ himself, in the vocative slot. He reported on his fourth day that "I now use these terms bapak/ibu extensively for anybody that I feel demands respect teachers, host parents (even of other students), and my own host parents" [diary entry, Day 4/28]. In starting to use Bapak/Ibu himself to address his host parents, Ross said he was "following Leo's lead - largely - although I'd been hearing them a lot around the school too - otherwise I wouldn't have felt confident to do it" [interview, Day 12/28]. We see again here how Ross benefited in his L2 learning from sharing his homestay with a fellow foreign student, Leo. This time Leo provided Ross with an implicit model for pragmatic practices, by virtue of Leo's status as someone who had the same role relationship to the host parents as Ross did himself. As Ross started to use Bapak and Ibu himself, this practice initially felt strange to him. On his fourth day he said:

(4) It took me a while to get used to addressing my host father/mother as bapak and ibu respectively - it still feels as though I'm referring to them as "dad" and "mum" which is a little disconcerting. And using bapak/ibu for the teachers at the language school is also strange. But I have come to find them as rather affectionate terms [diary entry, Day 4/28].

Ross displays a willingness here to tolerate some initial cultural unease in order to adopt this unfamiliar address term practice. He also displays a capacity to 
develop a positive understanding of the practice, by discerning the values of solidarity that it conveys. As for the term Mas "brother", Ross became aware of this term as a vocative term from his first day in the town, when he began to hear fellow passengers in public minivans say Mas to address the driver, and also heard his host father say Mas "all the time" to parking assistants, when driving the family around town in his car [interview, Day 12/28]. Ross thus profited from a range of opportunities for learning kin terms as vocative terms, both through formal instruction and in naturalistic contexts.

\subsubsection{Pronoun slot}

For learners who speak English as a first language, kin terms in the pronoun slot are harder to learn than kin terms in the vocative slot. They are less frequent in the input and are also less salient, as their difference from English makes it hard for some English speakers to notice them in the pronoun slot when they do occur (see Hassall 2013 for further discussion). However, during these early weeks Ross also learned that kin terms can be used in the pronoun slot. He demonstrated that knowledge in his first interview, stating that when he speaks to teachers in class, "for the you - I'll be saying Ibu" [interview, Day 12/28]. When asked how he came to know of that pragmatic practice, Ross relates a classroom incident which strikes him as crucial. A fellow student (from a different home university), Katrina, was reading aloud to the teacher a question which she had composed herself, and in that question she used anda in the pronoun slot. Ross said that he had regularly done the same thing himself, when reading aloud questions of his own to the teacher, without the teacher correcting him [interview, Day 12/28]. However, on this occasion, with this particular teacher, Katrina was seemingly corrected for doing it. Ross reported: "she [Katrina] was saying anda - and the teacher was like Ibu - and she [Katrina] was like anda [again] - and it was like - Ibu [by the teacher again] - so it was like yeah I think she was being corrected" [interview, Day 12/28]. Without access to the precise linguistic details of that episode, it is hard for us to judge how explicit or how salient that correction was. However, apparently it was performed in a sufficiently subtle manner for Ross to feel slightly unsure whether the teacher had in fact corrected Katrina. Yet Ross apparently managed to use that incident to revise his knowledge about address terms.

Ross's ability to extract value from that episode is fortunate, as this episode occurred amid a great deal of misleading input in Ross's classroom. The (in-house) coursebook used by Ross's class employs the word anda "constantly," as Ross himself observed [interview, Day 12/28]. In fact, that book never employs any term 
in the pronoun slot except for anda. As for kin terms, it employs them exclusively in the vocative slot, instead (e.g. Selamat pagi, $\underline{I b u}$ :[“safe-morning-mother”, i.e. "Good morning, mother"]). This gives the unfortunate impression that kin terms can only occur in the vocative slot. Ross has therefore learned a considerable amount from intrinsically low-quality pragmatic input in the classroom (cf. Niezgoda \& Röver 2001: 63). Ross was probably aided in his achievement by the fact that he was receiving his instruction in address terms at an optimal time, namely, during his study abroad, rather than prior to it (see e.g. Kasper \& Rose 2002; Kinginger 2009; Shively 2011). This made his classroom input optimally relevant to his everyday language use and enabled him to compare that input with what he heard outside the classroom and with his own use of address terms outside the classroom. In learning that kin terms can occur in the pronoun slot, Ross was also probably aided by his IL knowledge of Japanese (see Section 8.2). That IL knowledge probably primed him for the possibility that in Indonesian, too, noun phrases can replace a "you" pronoun, and that in some contexts they will be more appropriate than such a pronoun. In short, Ross had now taken a major step toward competence in L2 address terms, by gaining an awareness of Bapak/Ibu as respectful terms for both vocative and pronoun slots.

\subsection{Ross after two weeks: taking stock}

When asked after two weeks how he feels about his place within the host culture setting, Ross said, “everybody's very welcoming - everyone's very willing - and happy - to make you feel - as though you belong” [interview, Day 12/28]. He added, however, that he wants closer relationships with local students, and that, while he did talk with the local students who work as teaching assistants and receptionists at his language school, he interacted with them only within the school setting, which felt somewhat artificial. He said he'd like to "spend a lot more time socializing with Indonesians outside [the language school]," and remarked that "there's still a little bit of - distance between - other students in other departments and us" [interview, Day 12/28]. Ross shows here that he perceived himself (and the other Australians) as legitimate potential members of the wider student population at his host university and that he wanted fuller social participation within that group.

\subsection{Ross and his L2 environment: last two weeks}

In his last two weeks, Ross achieved his social goals. He became very friendly outside the language school with several local students who worked there, and 
through them, he also made "a couple of Indonesian friends" from among the main student population of the university [post-return interview]. Ross often went out with some or all of these young Indonesians, usually in a mixed group of Indonesians and a few other Australians, and acted as a social catalyst for the group by organizing events such as karaoke nights. He reported:

(5) I had some great experiences with Indonesians I hung out with [...] - this kind of like core little group that we had [...] - they loved hanging out with us - we had some really big nights (laughs) together - they were fantastic we had tons of fun with them and - and I loved it [post-return interview].

Most of the conversation on those occasions was in English and Ross said he himself only spoke Indonesian "when I was feeling especially confident - or when we were really just joking”; for example, exchanging friendly, one-word insults [post-return interview]. Nonetheless, he found these social relationships very rewarding. Ross's experiences are revealing of the range of identities which were available to him during a short stay. As a Caucasian, native Englishspeaking visitor from a wealthy western country, Ross possessed high value as a social companion in his Indonesian setting and found friendship readily offered to him, in striking contrast to the frustrating social experiences of study abroad participants in some other L2 settings (see e.g. US learners of French in Hoffman-Hicks 2000). During these last weeks, Ross started to speak Indonesian a great deal more at home, switching to using "mostly Indonesian" [post-return interview]. He remarked on this: "of course I felt pretty silly doing it but I thought - that's the only way I'm going to learn - so I did it [...] and sometimes I'd see [my homestay mother] smile like I guess the way we would smile if someone was talking to us in broken English" [post-return interview]. In this way, Ross persisted with creating opportunities for learning the language informally even when it involved a certain loss of face.

\subsection{Ross and address terms: last two weeks}

Ross learned a good deal more about address terms in his last weeks. He became explicitly aware that the pronoun anda is rarely used. As a result, he decided to drop anda from his repertoire and to replace it with the kin terms Mas/Mbak ("brother/sister") First, Ross learned his missing kin term Mbak itself. He reports that "after we met last time [i.e. interview on Day 12/28]. I started to hear Mbak everywhere", and cited as examples: hearing mbak used by staff at his language school to address each other, and hearing it used by his Indonesian friends to 
address serving staff in cafes [post-return interview]. As for Ross's learning that anda is uncommon, a trigger for that development was an incident near the end of his third week. A teacher in class was explaining a passive construction by means of a table drawn on the whiteboard, and as part of her explanation she wrote in one column a list of second person address terms. In that list she included all four kin terms Bapak/Ibu/Mas/Mbak and also the familiar pronoun kamu. However, Ross said, "the very interesting thing [...] was that Ibu Nia actually forgot to include anda in the list of personal pronouns when writing them up on the board" [diary entry, Day 23/28]. Ross added:

(6) and I asked her why? [...] I guess I was trying to think - what's behind it what's the subconscious reason - for forgetting [...] what I would consider to be a very key - kind of personal pronoun in English - it's - you - but she just didn't put that down at all - and I asked why not? - and she said o:h well: - we don't really use it much - and I was like o:h that's really interesting [post-return interview].

In this incident, Ross brought considerable attentiveness and curiosity to bear on his learning of address terms, by noticing a not very salient piece of input and asking his teacher about it. With his interest piqued in the status of anda, Ross quickly pursued the issue further. In a class later the same day he asked the young teaching assistant, Rini, if she personally uses anda all the time in Indonesian, "like we use you in English". Rini replied to him that she does not [post-return interview]. Ross remarked on this:

(7) it was only after that conversation with Rini that I started thinking - maybe I should be thinking differently - [...] and so I started thinking Mbak Rini and $I b u$ - and so on - I realized I shouldn't be thinking like you - you - in an English way

(Researcher: do you mean: - you thought - I shouldn't be thinking: anda?) yeah - exactly - anda - exactly [post-return interview].

Ross thus retained the belief that the pronoun anda in Indonesian is basically equivalent to "you" in English, but now, he also held the belief that anda unlike "you" - is uncommon. In his ability to hold those dual perceptions about anda, he is probably influenced by his prior study of Japanese; specifically, his IL knowledge about Japanese address terms (see Section 8.2).

In episodes above (Extracts [6] and [7]), Ross asked for metapragmatic information about the term anda from two expert speakers: a teacher and a teaching 
assistant. In this way he successfully compensated for the fact that no-one had ever offered him corrective feedback on his own non-L2-like use of anda (cf. Shively 2011). Soon afterward, Ross used that same learning strategy again: this time asking his host mother if she herself often uses the term anda in conversation. She replied that she never uses anda [diary entry, Day 23/28]. By now, Ross was convinced that using anda is a less authentic practice than using kin terms. He therefore started to reject the term anda as inconsistent with a stance of minimizing social-cultural distance from his Indonesian interlocutors. While continuing to address superiors in the pronoun slot as Bapak/Ibu, Ross now started to address everyone else in the pronoun slot as Mbak and Mas. He reported doing this "in everyday conversation in with Indonesians" [diary entry Day 24/28] and said that it was "with any Indonesian basically - so even with [young teaching assistants] I'd be like - Mbak Rini - Mbak Yuni - Mas Edo" [post-return interview]. As Ross increasingly adopted this practice of using kin terms in the pronoun slot, he felt its "strangeness" from an English perspective. He remarked:

(8) I have to admit I find it kind of cute/funny to engage with somebody in conversation and talk about them as though they're in a third person position, e.g. "What is mbak Rini doing tonight?" while talking to Rini. It's a good thing that I find it entertaining in this way, because it's helping me sound a little more culturally coherent than I have otherwise been coming across [diary entry, Day 24/28].

For learners of Indonesian who speak English as a first language, kin terms in the pronoun slot are more distant from L1 pragmatic norms than are kin terms in the vocative slot, and they are more culturally "confronting" as a pragmatic practice to adopt (see discussion in Hassall 2013). Ross showed in Extract (8) that he was willing to undergo a certain amount of initial unease in order to adopt this practice himself, and thereby achieve his goal of sounding culturally appropriate.

\subsection{Ross's knowledge of address terms on return}

In the post-test, Ross chose a kin term for the pronoun slot in every scenario. He never mentioned inappropriate anda as a possibility. Ross was thus able to choose appropriate terms of address to a wide range of interlocutors. However, in one test scenario did Ross reveal knowledge which is discernibly not accurate. To address the young local student who he has come to know very well socially over six weeks, Ross confidently chose "Mbak Yuni”. He said that by adding her given name (Yuni) to the term Mbak, he made Mbak sound familiar enough to 
use to her; and as evidence for that belief he cited his real-life practice of addressing his Indonesian friends as "Mbak Rini" and "Mas Edo" and so on [post-test]. However, in fact, adding a given name still does not make Mas/Mbak sound familiar enough for a highly familiar addressee. Young people who know each other that well would typically have stopped calling each other by kin terms, and started addressing each other as for example, kamu instead. Ross did mention kamu as a possibility for this scenario, but rejected it, saying that he never used it as he preferred to use Mas and Mbak instead [post-test]. Thus, on his return Ross displayed a strong willingness to use, perhaps even to overuse, kin terms: a mode of address which is highly specific to the L2 culture and very distant from the pragmatic norms of English.

\subsection{Ross and the L2 culture setting: after return}

Ross's comments on his return about his experiences of the L2 culture setting were entirely positive. He said:

(9) I'm actually missing [name of town] so much - you have no idea - as soon as I got back I thought - I wish I could stay there and finish my whole uni [versity program] over there [...] it was just incredible [...] the language - the culture - the people - everything - I just love it [post-return interview].

After he returned, Ross quickly finished his Indonesian major, becoming highly active in the Indonesian Students' Association on campus. When I met Ross by chance, shortly after he graduated, he was about to depart on a business trip to Indonesia, in order to begin setting up his own import business between Indonesia and Australia. Ross's success in learning Indonesian address terms is striking. It shows how during a very short stay abroad, a beginner L2 learner with a fortuitous blend of history, stances, and engagements can learn a good deal about a socially sensitive L2 pragmatic feature. Ross's experiences and learning outcomes come into sharp relief when seen against those of fellow participant, Amy.

\section{Amy}

\subsection{Background}

"Amy" is a thoughtful, self-possessed Australian, Caucasian student in her late twenties who speaks English as a first language. She had done well in her 
first-semester Indonesian course at her home university, but had then become very busy with her part-time office job and had withdrawn from her secondsemester course half-way through, deciding to make up the equivalent course over summer instead, by study abroad. Amy had chosen Indonesian for her language major mainly because friends of hers in higher level Indonesian classes had told her that the full-year study abroad program for advanced students of Indonesian was a highly enjoyable year, and Amy had decided she wanted to do that program as well. Amy had studied languages a little in the past: elementary Italian at primary school and elementary French in early high school. However, unusually for students in her cohort, she had never been abroad before. Asked about her feelings regarding her coming stay in Indonesia, Amy said:

(10) well what I'm expecting or at least - hoping is that people are going to be quite friendly - u:m I've heard people tell me that [...] when I try and speak even if it's wrong - even if comes out - as nonsensical (laughs slightly) - you'll get a - a friendly response [pre-departure interview].

Amy thus hoped to find her L2 culture setting a friendly and non-threatening one for a learner equipped with elementary speaking ability.

\subsection{Amy's knowledge of address terms before departure}

Amy revealed in the pre-test that she knew two terms for the pronoun slot: anda and kamu. She confidently chose anda in nearly every test scenario. She chose anda for all three "superior" addressees and also for all three non-intimate, nonsuperior addressees. Anda would be highly inappropriate to all of these addressees. It would be inadequately respectful for the superiors and would sound distinctly odd for the other three addressees due to its extreme formality. In only one test scenario was Amy able to make an appropriate choice, choosing familiar kamu to the local student she had come to know very well. This preference of Amy for anda owes a lot to the negative influence of classroom instruction at her home university. Amy, like most other students in her study abroad cohort, had been given intensive practice using anda during her firstsemester course. Early in her second-semester course, she had been instructed about Bapak/Ibu as terms for the pronoun slot, both through metapragmatic information and through a good deal of spoken practice. However, by the time of the pre-test two months later, she had forgotten that Bapak and Ibu can occur in the pronoun slot. She mentioned Bapak/Ibu in the pre-test as vocative terms, but never as pronoun slot terms. 


\subsection{Amy and her L2 environment: first two weeks}

Amy lived in a homestay with her host mother (aged around 40) and a sister of her host mother (aged around 30). There were also three small children, who Amy did not mention again after initially noting their existence. At her own request, Amy had been placed as the only foreign guest in the homestay. In her language school, Amy was the sole student in her elementary class. She was happy with her formal course; she found it fast-paced and challenging, but wellorganized so that she could keep up [interview, Day 12/28]. In her first interview Amy displayed a strong self-identity as a formal language learner, describing in enthusiastic detail the structure of her course, the types of class activities, and her own systematic routine for preparing for each day's new classes [interview, Day 12/28]. Amy did not use much Indonesian outside class. Both women in her homestay spoke English very well, which discouraged Amy from trying hard to stick to Indonesian at home. She said:

(11) if I had had the - the experience I had now and the insight I have now - I guess I wouldn't have requested - being on my own - just because - Ibu Eny has amazing - like she's really good at English [...] and Fitri has really good English as well - [...] it's so easy to be lazy because - if I don't know a word I won't - search for it I'll just [...] drop in the: - the English [interview, Day 12/28].

Being the sole foreign student in the homestay did not maximize Amy's exposure and use of the L2, as it can potentially do for study abroad learners (see Churchill 2005; cited in Kinginger 2009: 190). Rather, in Amy's case it meant that she was the only learner of Indonesian in the house, which made learning Indonesian a less powerful determinant for the choice of shared code, so that the code choice readily drifted to the strongest shared code of English. Amy also kept quite a strong focus on her home network of friends and family during her time outside classes, through electronic communication (see Kinginger 2009: 149). She spent some time on Facebook and on emails to home each day before classes and regularly checked online news reports on events in Australia; remarking "At the moment I'm sort of fixated on all the photos [of the extreme weather and flash floods in 2010] coming out of Melbourne" [interview, Day 12/ 28]. When Amy went out around town, she very often went on her own. Occasionally a person around town would strike up a conversation with her, but Amy had trouble participating in even simple conversations. She told of one such experience, where a fellow passenger greeted her in a public minivan with 
a routine greeting phrase, Mau ke mana? [go-to-where, i.e. "Where are you going?’]:

(12) I felt really bad [...] it was only after I got off - that I realized - she'd been saying - mau ke mana - I mean she was just saying [...] how are you [...] I kept saying - uh - tidak - mendengar [not-hear, i.e. "I don't hear"] tidak mendengar - and then sort of - looked the other way [interview, Day 12/28].

Amy's low speaking proficiency thus made it hard for Amy to talk with friendly strangers in public, which restricted her access to potential L2 learning situations.

\subsection{Amy and address terms: first two weeks}

Amy quickly developed a strong awareness of two terms for the vocative slot; ones which she already knew before she departed: ibu and bapak. This awareness was triggered by a remark during the pre-course orientation talk by the director, Tina, which Amy reported as follows: "Tina emphasized to the group the importance of addressing teachers using bu or pak" [diary entry, Day 1/28]. Considering the pragmatics of these terms (see Section 5.2), it is likely that the director intended that remark of hers partly or chiefly as an injunction to address teachers as Bapak/Ibu in the pronoun slot. However, because Amy only knew the terms Ibu and Bapak as vocative slot terms, she interpreted the director's remark in line with that understanding: as an injunction to add ( $\mathrm{Ba}$ )pak and (I)bu frequently in the optional, vocative slot. Amy duly reports trying to remember to add those kin terms in the vocative slot to her phrases of greeting, thanking, and taking leave, when speaking to teachers and to the director of the school; for example, Sampai nanti Ibu (until-later-mother, i.e. "See you later, mother" [diary entry, Day 10/28]). Amy thus gained access here to metapragmatic information which potentially could have helped her to realize that Bapak/Ibu - not anda - is the appropriate way to address superiors. However, Amy's baseline knowledge about address terms was too low for her to be able to benefit greatly from that information. Amy also learned of a new term for the vocative slot: the kin term Mas. In her very first class, her teacher told her that it's appropriate for her to address the 22-year-old teaching assistant Edo as "Mas Edo" [interview, Day 12/28]. Once again, that advice was probably intended to apply to the pronoun slot as well as to the vocative slot, but once again Amy interpreted it as applying only to the vocative slot. She said that she tried 
thereafter to remember to add Mas vocatively, when talking to Edo [interview, Day 12/28]. Thus, Amy was evidently not revising her knowledge in the pronoun slot, where it was most seriously inaccurate. I checked this during her Day 12 interview, by asking Amy explicitly whether, in any of her diary entries or her oral remarks about the kin terms Bapak, Ibu, and Mas, she had been referring to the pronoun slot as well. I asked her: "[...] is it also like - Mas tinggal di mana? [brother-lives-where, i.e. 'Where do you live?'] - like you”. Amy denied this vigorously, saying: "o:h - no - when I'm asking someone something [i.e. for the pronoun slot] I'll say anda - I mean that's for the you - it's only if I want to get someone's attention I'll say - Ibu or Pak - or Mas for Edo" [interview, day 12/28]. In short, at this point in her stay, Amy shows no awareness that her knowledge of terms for the pronoun slot is inaccurate.

\subsection{Amy after two weeks: taking stock}

At the two-week point, Amy felt somewhat alienated from her L2 culture setting. She said:

(13) I think I feel like I'm in a little bit of a bubble when I go out by myself just becaus:e - (inbreath) I am quite apprehensive about speaking to people just because I'm worried that I don't have the language - and also - you know everyone's - just doing their own thing - so: [...] it feels like I'm just here on a sightseeing holiday or something. - [...] I'm sort of not existing - in the - same - sphere as them - almost [interview, Day 12/28].

Amy's low language proficiency evidently contributed to making her feel socially isolated, which in its turn was detrimental to her language learning. She also reported on how her own experience seems to be falling short of the experiences of female Australian friends from her home university:

(14) I'm not rea::ly feeling a connection to the place - [...] I have friends who have come over here and have done programs like this and [...] it's been some kind of - defini:ng - moment in their lives where they realized oo:h I love this place (faintly) (a:h) whereas - I dunno: - not feeling it (laughs slightly) [interview, Day 12/28].

At this stage, Amy seemed to feel she had little legitimate place in the L2 culture setting apart from in her role as a formal language student. 


\subsection{Amy and her L2 environment: last two weeks}

Amy came to feel increasingly unhappy in her L2 environment. She found herself unable to summon enough interest in learning Indonesian to stick to the stipulated language-related topics for her diary entries. She said:

(15) I tried to keep it - based around the - the language - and stuff like that but [...] I think towards that second part of the course I was getting quite homesick - and a little bit fed up and a little bit - tired - of the whole experience - so some of it is just me griping and bitching [post-return interview].

She related two painful encounters of being cheated by public minivan drivers. In one of those encounters her low Indonesian proficiency laid her open to exploitation: she got into the empty minivan, handed the driver a five thousand rupiah note to pay for the fare which she knew was two thousand rupiah, and stated in Indonesian, with unfortunate ambiguity: "I only have five thousand" (Saya hanya punya lima ribu: I-only-have-five-thousand). The driver replied to her that that was okay, took the note, and just sat there, pretending not to understand her attempts to ask for change, until she got out in disgust "and crankily walked home" [post-return interview]. She reflects on that episode as follows:

(16) Don't have a very trusting opinion of the Indonesian general public today. In particular men, and in particular men driving transport. [...] I realise now that every time I meet new people [...] there's a big, flashing warning in my mind that this person may only be interested in how much money they can get from me [diary entry, Day 21/28].

After Amy was cheated on the fare by another minivan driver, she reflected:

(17) it's not the money that I have issue with [...], but it's the feeling that different rules apply, or don't apply for me based on my race. It discourages me from ever wanting to work in Indonesia because I know that that will be a constant struggle if I ever had to live here [diary entry, Day 26/28].

In her homestay, too, Amy started to feel increasingly unhappy. She felt overprotected by the two women in her homestay and craved autonomy. Three diary 
entries are devoted to that theme. One entry began: "I feel bad about Fitri [the sister] always having to check up on me. She's become the default babysitter" [diary entry, Day 19/28]. Amy sneaked out of the homestay early one morning, so that she could ride the public minivan to school by herself for once. Nothing was said directly to her about it, but she reported "I feel like I'm kept closer tabs on now" [diary entry, Day 19/28]. Amy said that she was grateful for the two women's concern for her and acknowledged that "in a way, only having broken Indonesian skills does make me more vulnerable” [diary entry, Day 23/28]. However, she still chafed against their supervision. To sum up, Amy took an increasingly embattled stance toward her L2 culture setting. Her low L2 proficiency contributed to this. It made service providers more inclined to try to cheat her, which in turn badly colored her outlook on the L2 culture setting; and it made her homestay family more inclined to perceive her as helpless and hence to treat her in ways which she found oppressive.

As for Amy's gender, she herself mentioned it only once, implicitly (see Extract 16). However if she had been talking to a female researcher she may have conveyed more emphatically that she perceived her position as a female westerner as crucial in determining her experiences (as it has been for female learners in various other study abroad settings: see a review by Kinginger 2009: 184196). For example, her gender may have encouraged male strangers such as transport drivers to perceive her as a soft target for financial exploitation, or encouraged her homestay family to perceive her as a vulnerable figure in need of protection.

Amy continued to study hard for her course. In her final interview she described her diligent preparation for her last weeks of classes and for her final assessment tasks [post-return interview]. However, outside the classroom, she now tried to speak English whenever she could. She remarked: "I think I was just really tired at that point - (inbreath) - so: - where I had to for class I would use [Indonesian] - but - just in general conversation and even at home [...] like my brain just wasn't up for it - at all” [post-return interview]. During these last weeks Amy displayed little investment in language learning outside the requirements of her course. She seemed to feel she was using all her energy simply to manage her daily life in the L2 culture setting.

\subsection{Amy and address terms: last two weeks}

During these last two weeks, Amy did not revise her knowledge about address terms for the pronoun slot. She did, however, learn one more term for the vocative slot: her one missing kin term, Mbak [sister]. She said she learned 
this term Mbak by being addressed as Mbak herself at her language school, explaining that when she walked into the school in the mornings, "the reception girls would say - selamat pagi - Mbak Amy” (safe-morning-sister-Amy; i.e. "Good morning, sister Amy" [post-return interview]). This shows that even during a phase of Amy's sojourn when she felt strongly positioned as an outsider in her L2 environment, she was still able to notice a vocative term in naturalistic interaction and to remember noticing that term, thereby learning it successfully. However, Amy evidently regarded this term Mbak purely as a vocative term (as confirmed in the post-test). Also, Amy never used the term Mbak herself - "not a single time" - for the reason that the difficult initial consonant cluster $(/ \mathrm{mb} /)$ made her nervous that she would pronounce Mbak wrongly and inadvertently say Pak "father" to someone instead [post-return interview].

\subsection{Amy's knowledge of address terms on return}

Amy showed no change in knowledge from pre-test to post-test about terms in the pronoun slot. She once again confidently chose anda to all three superior addressees and to all three non-superior, non-intimate addressees. Thus, she chose inappropriate anda to the same range of addressees as she had done before her departure. The researcher, to be quite certain that Amy had not learned that kin terms are used the pronoun slot, waited until the end of the post-test session, then told her explicitly of the existence of kin terms in the pronoun slot, and asked her whether she had ever come across that way of addressing people. She replied emphatically: "No::o - and it never occurred to me until this moment that you could do that [...] no - if I was ever speaking in a situation where I needed to use Ibu - Pak - Mas - or Mbak [i.e. in the vocative slot] I would just use anda" [post-test]. Amy's failure to learn that she had been addressing nearly everyone in Indonesia by an inappropriate term is consistent with her sense that her only legitimate identity in the L2 culture setting was that of formal classroom learner. The formal content of her course did not cover the issue of how to address people in the pronoun slot, and consistent with that, she made no discernible progress in learning it. At the same time, Amy was disadvantaged compared to Ross in the timing of her formal instruction about address terms. Amy's instruction about terms for the pronoun slot, unlike Ross's, included explicit coverage of kin terms. However, Amy received her instruction before she embarked on her sojourn, at a time when it bore no relevance to her everyday experiences of language outside the classroom, and was therefore likely to have less relevance to her. 


\subsection{Amy and the L2 culture setting: after return}

Amy summed up her impressions of her study abroad experience as follows:

(18) I - I have the idea now that there's a big schism - like the people that I lived with and the people that I came in contact with - they were really lovely honest people - but the other side of it is that if you're doing any kind of day to day business in Indonesia like if you're just living there and you don't personally know people - they're not - always very nice? (laughs slightly) [...] being in a homestay gave me - at least some kind of - saving grace - as far as Indonesia goes [...] - like - I could see that there is - there is good people there and there is a heart there but um: yeah [post-return interview].

Amy's short stay was a powerful experience for her. She did not find her L2 culture setting a friendly one, as she had hoped. She came to feel insistently and unpleasantly positioned as an outsider and began to abandon the notion of ever living in Indonesia for a longer time. Along with that, in stark contrast to Ross, she learned nothing discernible about pronoun slot terms for addressing people. Amy received a very good formal grade for her summer in-country Indonesian course. However, during the following semester, she transferred to a different academic program, ceasing her study of Indonesian.

\section{Conclusions}

Ross and Amy adopted different identities within their L2 culture setting, and this strongly influenced their learning of L2 address terms. The study thus supports Block's (2003) claim that "very often it is how the individual negotiates and carves out an identity in the target language which ultimately determines relative success or failure" (2003: 55), while showing the specific relevance of this claim to pragmatic development in study abroad. At the same time, this study through its sharp focus on the path of language learning helps us to dispel a simplistic view of the relationship between identity construction and SLA. Ross did indeed display highly favorable stances toward his L2 environment, but his success was also aided by, among other things, his prior knowledge of other foreign languages, and by a crucial incident in his classroom, without which he might have learned a good deal less during his short stay. Amy was greatly constrained in her ability to learn L2 pragmatic norms by her stances toward the 
L2 environment, but she nonetheless did show some capacity to learn new address terms through naturalistic interactions, even during her most strongly alienated phase. Learning outcomes for individuals thus emerge out of a complex of unique factors.

Ross's story shows that learners with low initial proficiency can make striking pragmatic gains during study abroad. They can acquire features which are formally simple, frequent in input, and high in perceptual salience. By those criteria, Indonesian address terms in the pronoun slot are relatively easy. To serve as a contrast, speech acts such as refusals, which are formally complex and involve negotiation over multiple turns, will be beyond the ability of low-proficiency participants to acquire successfully. The study also helps us understand how certain specific factors influence L2 learning during study abroad. As regards low proficiency, the study shows concrete ways in which low proficiency can impede L2 learning, while also showing that those proficiency effects do not operate in the case of all individuals. Considering prior study of foreign languages, the study shows specific ways in which a learner's knowledge of another language helped him learn a pragmatic feature of his target L2. The study also suggests strong benefits for providing formal instruction in pragmatics during the study abroad sojourn and demonstrates several ways in which L2 learners may benefit from the presence of fellow learners during their naturalistic interactions.

Acknowledgments: I am grateful to an anonymous reviewer for a great many valuable comments.

\section{Transcription conventions}

\begin{tabular}{|c|c|}
\hline Day $12 / 28$ & Day 12 of a 28 -day program \\
\hline - & short untimed pause \\
\hline-- & longer untimed pause \\
\hline a:: & $\begin{array}{l}\text { sound before colon is elongated (more colons indicates greater } \\
\text { elongation) }\end{array}$ \\
\hline augh) & brackets indicate non-verbal information \\
\hline & rising intonation \\
\hline & material omitted by researcher \\
\hline
\end{tabular}

\section{References}

Bardovi-Harlig, Kathleen. 2013. Developing L2 pragmatics. Language Learning 63(s1). 68-86. Block, David. 2003. The social turn in second language acquisition. Washington, DC:

Georgetown University Press. 
Churchill, Eton. 2005. A case study of gendered language learning at home and abroad. Paper presented at the Association Internationale de Linguistique Appliquée, Madison, WI, July 2005.

DuFon, Margaret A. 2000. The acquisition of linguistic politeness in Indonesian by sojourners in naturalistic interactions. Hawai'i: University of Hawai'i PhD dissertation. Dissertation Abstracts International-A, 60/11: 3985.

Ginsberg, Ralph \& Laura Miller. 2000. What do they do? Activities of students during study abroad. In Richard Lambert \& Elana Shohamy (eds.), Language policy and pedagogy: essays in honor of $A$. Ronald Walton, 237-260. Philadelphia, PA: John Benjamins.

Hassall, Tim. 2012a. Pragmatic development in study abroad contexts. In Carol Chapelle (ed.), Encyclopedia of applied linguistics (Volume 8), 4516-4522. Hoboken, NJ: Wiley-Blackwell.

Hassall, Tim. 2012b. Acquiring address terms in Indonesian: a diary study. In Christina Gitsaki \& Richard Baldauf, Jr. (eds.), Future directions in applied linguistics: Local and global perspectives, 218-233. Newcastle, UK: Cambridge Scholars Publishing.

Hassall, Tim. 2013. Pragmatic development during short-term study abroad: The case of address terms in Indonesian. Journal of Pragmatics 55. 1-17.

Hoffman-Hicks, Sheila D. (2000). The longitudinal development of French foreign language pragmatic competence: Evidence from study abroad participants. PhD, Indiana University. Dissertation Abstracts International-A, 61(2): 591.

Jenson, Kenneth. 1988. Forms of address in Indonesian. ITL Review of Applied Linguistics 81. 113-138.

Kasper, Gabriele \& Ken Rose. 2002. Pragmatic Development in a Second Language. Malden, MA: Blackwell.

Kinginger, Celeste. 2008. Language learning in study abroad: Case studies of Americans in France. Language Learning 92(s1). 1-124.

Kinginger, Celeste. 2009. Language learning and study abroad: A critical reading of research. New York: Palgrave MacMillan.

Lafford, Barbara \& Joseph Collentine. 2006. The effects of study abroad and classroom contexts on the acquisition of Spanish as a second language. In Barbara Lafford \& Rafael Salaberry (eds.), Spanish second language acquisition: From research findings to teaching applications, 103-126. Washington, DC: Georgetown University Press.

Magnan, Sieloff \& Michele Back. 2007. Social interaction and linguistic gain during study abroad. Foreign Language Annals 40(1). 43-61.

Marriott, Helen. 1995. The acquisition of politeness patterns by exchange students in Japan. In Barbara Freed (ed.), Second language acquisition in a study abroad context, 197-224. Amsterdam: John Benjamins.

Miller, Laura \& Ralph Ginsberg. 1995. Folklinguistic theories of language learning. In Barbara Freed (ed.), Second language acquisition in a study abroad context, 293-315. Amsterdam: John Benjamins.

Murphy-Lejeune, Elizabeth. 2002. Student mobility and narrative in Europe: The new strangers. New York: Routledge.

Niezgoda, Kimberly \& Carsten Röver. 2001. Pragmatic and grammatical awareness: a function of the learning environment? In K. Rose \& Kasper Gabriele (eds.), Pragmatics in language teaching, 63-79. Cambridge: Cambridge University Press.

Norton, Bonny \& Carolyn McKinney. 2011. An identity approach to second language acquisition. In Dwight Atkinson (ed.), Alternative approaches to second language acquisition, 73-94. Abington, OX: Routledge. 
Pavlenko, Aneta. 2002. Poststructuralist approaches to the study of social factors in second language learning and use. In Vivian Cook (ed.), Portraits of the L2 user, 277-302. Clevedon: Multilingual Matters.

Shively, Rachel. 2008. Politeness and social interaction in study abroad: Service encounters in L2 Spanish. Minnesota: University of Minnesota PhD dissertation. my.ilstu.edu/ rshivel/ publications.html (accessed 11 July 2010).

Shively, Rachel. 2011. L2 pragmatic development in study abroad: A longitudinal study of Spanish service encounters. Journal of Pragmatics 43(6). 1818-1835.

Shively, Rachel. 2013. Learning to be funny in Spanish during study abroad: L2 humor development. The Modern Language Journal 97. 930-946. 